\title{
Lung transplantation
}

\author{
Keith C. Meyer
}

Address: UW Lung Transplant \& Advanced Pulmonary Disease Program, Section of Allergy, Pulmonary and Critical Care Medicine, Department of Medicine, University of Wisconsin School of Medicine and Public Health, 600 Highland Ave, Madison, WI 53792, USA

Email: Kcm@medicine.wisc.edu

Fl000Prime Reports 2013, 5:16 (doi:10.12703/P5-16)

This is an open-access article distributed under the terms of the Creative Commons Attribution-Non Commercial License (http://creativecommons.org/licenses/by-nc/3.0/legalcode), which permits unrestricted use, distribution, and reproduction in any medium, provided the original work is properly cited. You may not use this work for commercial purposes.

The electronic version of this article is the complete one and can be found at: http://fl000.com/prime/reports/m/5/I6

\begin{abstract}
Lung transplantation may be the only intervention that can prolong survival and improve quality of life for those individuals with advanced lung disease who are acceptable candidates for the procedure. However, these candidates may be extremely ill and require ventilator and/or circulatory support as a bridge to transplantation, and lung transplantation recipients are at risk of numerous post-transplant complications that include surgical complications, primary graft dysfunction, acute rejection, opportunistic infection, and chronic lung allograft dysfunction (CLAD), which may be caused by chronic rejection. Many advances in pre- and post-transplant management have led to improved outcomes over the past decade. These include the creation of sound guidelines for candidate selection, improved surgical techniques, advances in donor lung preservation, an improving ability to suppress and treat allograft rejection, the development of prophylaxis protocols to decrease the incidence of opportunistic infection, more effective therapies for treating infectious complications, and the development of novel therapies to treat and manage CLAD. A major obstacle to prolonged survival beyond the early post-operative time period is the development of bronchiolitis obliterans syndrome (BOS), which is the most common form of CLAD. This manuscript discusses recent and evolving advances in the field of lung transplantation.
\end{abstract}

\section{Introduction}

Various forms of advanced lung disease often relentlessly progress to respiratory failure and death despite the use of various state-of-the-art therapies given in an attempt to arrest the disease process. Lung transplantation is the only therapy that can prolong survival and improve quality of life for such patients $[1,2]$. However, survival outcomes for lung transplant recipients remain significantly lower than those for recipients of other solid organs (Table 1). Caregivers and patients must carefully weigh the risks and benefits of this procedure with the understanding that it is a palliative measure that can prolong survival and improve quality of life, but a myriad of complications can arise at the time of allograft implantation and beyond that can lead to subsequent poor quality of life and/or a fatal outcome. There are several recent developments in the field that hold promise for improving allograft function: refining criteria for selecting candidates for the transplant wait-list; increasing the donor organ pool and the quality of implanted lungs via the use of donation after cardiac death (DCD) donors and the use of ex-vivo lung perfusion (EVLP) techniques following organ procurement in preparation for implantation; identifying immunosuppressive regimens that optimally prevent post-transplant allograft rejection yet minimize the risk of opportunistic infection; prophylactic antimicrobial therapies to prevent opportunistic infections; and, most importantly, an improved understanding of chronic lung allograft dysfunction and rejection that will lead to advances that prevent the development of chronic lung allograft dysfunction and its subsets of BOS and restrictive allograft syndrome as well as therapies that can arrest progressive loss of allograft function should CLAD develop (see Tables 2 and 3). Lastly, appropriate palliative measures need to be incorporated into post-transplant management protocols to relieve symptoms when recipients develop refractory loss of allograft function due to the appearance of advanced and progressive CLAD. 
Table I. I- and 3-year survival for solid organ transplantation in the United States*

\begin{tabular}{|c|c|c|}
\hline Organ & $\begin{array}{l}\text { I year graft survival } \\
(1 / 1 / 2009-6 / 30 / 2011)^{* *}\end{array}$ & $\begin{array}{l}3 \text { year graft survival } \\
(7 / 1 / 2006-12 / 3 \mid / 2008)^{* *}\end{array}$ \\
\hline Lung & $\begin{array}{c}83.8 \% \\
(N=4,147)\end{array}$ & $\begin{array}{c}63.9 \% \\
(\mathrm{~N}=3,474)\end{array}$ \\
\hline Heart-Lung & $\begin{array}{c}80.0 \% \\
(N=73)\end{array}$ & $\begin{array}{c}57.9 \% \\
(N=55)\end{array}$ \\
\hline Heart & $\begin{array}{c}89.9 \% \\
(N=4,595)\end{array}$ & $\begin{array}{c}80.9 \% \\
(\mathrm{~N}=4,440)\end{array}$ \\
\hline Kidney & $\begin{array}{c}93.8 \% \\
(N=38,9 \mid 5)\end{array}$ & $\begin{array}{c}85.8 \% \\
(\mathrm{~N}=38,458)\end{array}$ \\
\hline Kidney-Pancreas & $\begin{array}{c}\text { Kidney - } 94.8 \% \\
\text { Pancreas }-88.6 \% \\
(\mathrm{~N}=2,040)\end{array}$ & $\begin{array}{c}\text { Kidney - 86.5\% } \\
\text { Pancreas - 79.6\% } \\
(\mathrm{N}=2,|3|)\end{array}$ \\
\hline Liver & $\begin{array}{c}86.5 \% \\
(N=13,249)\end{array}$ & $\begin{array}{c}75.8 \% \\
(\mathrm{~N}=13,467)\end{array}$ \\
\hline Intestine & $\begin{array}{c}70.9 \% \\
(N=202)\end{array}$ & $\begin{array}{c}53.1 \% \\
(N=190)\end{array}$ \\
\hline
\end{tabular}

*Data for National Graft Survival from Scientific Registry of Transplant Recipients (www.srtr.org/csr/current/centers/default.aspx - released July 20I2)

**Time window when transplants were performed

Table 2. Risk factors associated with bronchiolitis obliterans syndrome

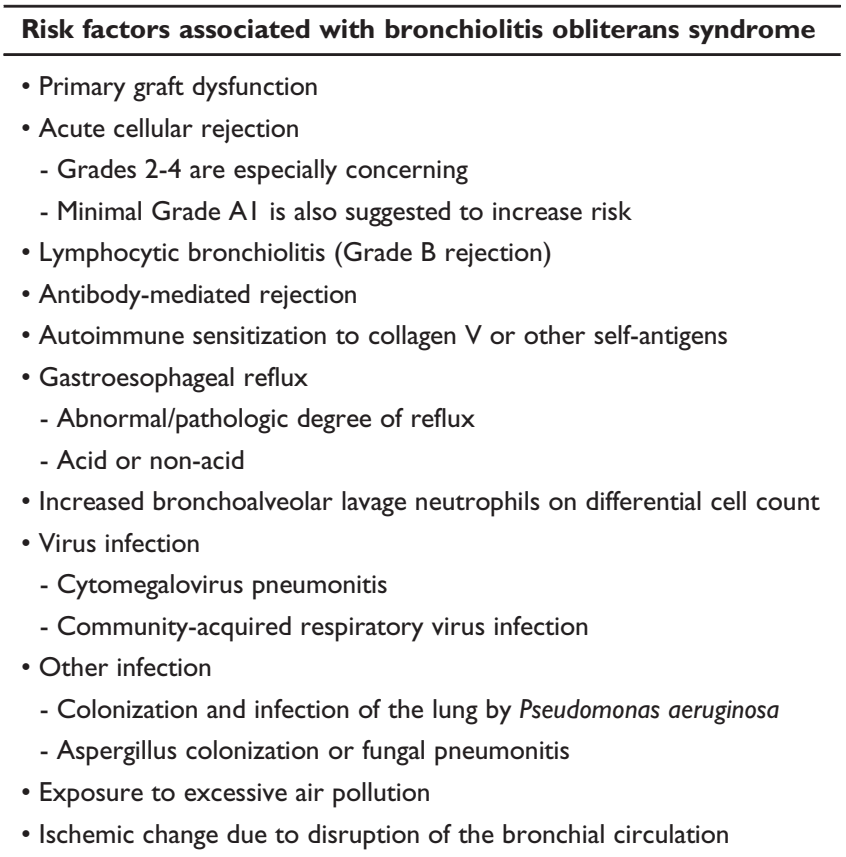

\section{Recent advances \\ Implementation of the lung allocation scoring system in the United States}

The lung allocation scoring (LAS) system $[3,4]$ was adopted in the United States in 2005 in preference to the previous time-based system (time on the lung transplant waitlist) to a need-based ranking system for lung allocation. Priority scores for transplantation are now computed and assigned on the basis of urgency (risk of death without transplant) and the degree to which transplant can extend survival. More severely ill patients tend to get higher scores, and diagnosis is the most influential parameter. Consequently, patients with idiopathic pulmonary fibrosis have become the predominant group receiving transplants, and there has been a progressive increase in the percentage of transplants for patients $\geq 65$ years of age. However, organ allocation appears to have become substantially more effective, and the total number of transplants has risen as deaths on the waitlist and waiting time have declined. However, outcomes have been shown to be worse for recipients with very high LAS scores [5-9], although outcomes for high-risk patients do appear to be improving [10,11]. Improved models to predict post-transplant outcomes are needed $[12,13]$, and other candidate characteristics, such as frailty [14], need to be considered as potential components of the LAS system to better identify candidates at high risk of poor outcome.

\section{Donor-recipient human leukocyte antigen matching}

Newly developed Luminex ${ }^{\circledR}$ solid phase assays for human leukocyte antigen (HLA) antibody detection have recently replaced complement-dependent serological techniques $[15,16]$. Adoption of these assays has improved pretransplant detection and identification of antibodies (pre-sensitization) against donor HLA and allows virtual cross-matching during the allocation and match process (to avoid transplants in patients who are presensitized to donor HLA antigens). By accurately predicting a donor cross-match result, bead-based virtual cross-matching has improved access for sensitized thoracic transplant recipients to organs outside their immediate region $[17,18]$. While technical and interpretive challenges remain, solid phase antibody assays have significantly improved transplant practice and outcomes $[19,20]$, and various technical issues are gradually being resolved and optimal cutoff values determined.

\section{Donation after cardiac death}

The use of DCD donors (donors with non-beating hearts who have undergone planned and controlled withdrawal of life support) has provided an additional pool of donated organs as an alternative to the traditional braindead donor. Reports in the literature indicate that recipient outcomes are similar to those for lungs transplanted from brain-dead donors [21,22].

\section{Ex-vivo lung perfusion}

Ex vivo lung perfusion (EVLP) has recently emerged as a technique that can be used to evaluate and recondition lungs following explantation from a donor, such that the function of marginal/injured lungs can be improved and significant, persistent dysfunction can be identified prior to recipient implantation [23-29]. Lungs are perfused with 
Table 3. Emerging phenotypes of CLAD: key features*

\begin{tabular}{|c|c|c|c|}
\hline Entity & Classic BOS & NRAD & RAS \\
\hline \multirow[t]{2}{*}{ Time of Onset } & $\begin{array}{l}\text { - Late (usually } 2-3 \text { years post-transplant, } \\
\text { but may occur earlier) }\end{array}$ & \multirow[t]{2}{*}{$\begin{array}{l}\text { - Usually occurs early (e.g. 3-6 months } \\
\text { post-transplant) }\end{array}$} & $\begin{array}{l}\text { - Tends to occur later but may occur at any } \\
\text { time }\end{array}$ \\
\hline & $\begin{array}{l}\cdot \approx 80 \% \text { prevalence at } 10 \text { years } \\
\text { post-transplant }\end{array}$ & & $\begin{array}{l}\text { - Accounts for approximately } 1 / 3 \text { of } \\
\text { CLAD cases }\end{array}$ \\
\hline Physiology & $\begin{array}{l}\text { - Obstructive (FEVI } \leq 80 \% \text { of stable } \\
\text { baseline value) }\end{array}$ & $\begin{array}{l}\text { - Obstructive (FEVI } \leq 80 \% \text { of stable } \\
\text { baseline value) }\end{array}$ & $\begin{array}{l}\text { - Restrictive (e.g. FEVI } \leq 80 \% \text { and TLC } \\
\leq 90 \% \text { of stable baseline values) }\end{array}$ \\
\hline \multirow[t]{3}{*}{ HRCT Imaging } & - Air trapping often present & \multirow{3}{*}{$\begin{array}{l}\text { - Changes of bronchiolitis ("tree-in-bud", } \\
\text { thickened airway walls, peri-bronchiolar } \\
\text { infiltrates often present) } \\
\cdot \pm \text { air trapping }\end{array}$} & $\begin{array}{l}\text { - Parenchymal infiltrates usually present } \\
\text { (DAD often present) }\end{array}$ \\
\hline & - + bronchiectasis & & $\cdot \pm$ bronchiectasis \\
\hline & & & $\cdot \pm$ air trapping \\
\hline \multirow[t]{3}{*}{ Histopathology } & \multirow{3}{*}{$\begin{array}{l}\text { - OB (difficult to diagnose via } \\
\text { transbronchial biopsy) }\end{array}$} & \multirow[t]{3}{*}{ - Cellular bronchiolitis } & - Fibrosis (thickened septae and pleurae) \\
\hline & & & - DAD often present \\
\hline & & & $\cdot \pm \mathrm{OB}$ \\
\hline \multirow[t]{2}{*}{ Clinical course } & - Typically progressive but may stabilize & \multirow{2}{*}{$\begin{array}{l}\text { - High likelihood of significant response } \\
\text { to azithromycin (may no longer meet } \\
\text { criteria for persistent BOS if recipient is } \\
\text { an azithromycin responder) }\end{array}$} & - Tends to be relentlessly progressive \\
\hline & $\begin{array}{l}\text { - Recipients may have coexistent } \\
\text { chronic bacterial infection }\end{array}$ & & - Significantly worse prognosis than BOS \\
\hline \multirow[t]{2}{*}{ Other } & $\begin{array}{l}\text { - Usually responds poorly to } \\
\text { pharmacologic therapies }\end{array}$ & \multirow{2}{*}{$\begin{array}{l}\text { - BAL neutrophilia (e.g. } \geq 15 \% \text { on } \\
\text { differential cell count) correlates with } \\
\text { response to azithromycin therapy }\end{array}$} & \multirow[t]{2}{*}{$\begin{array}{l}\text { - Increased risk of RAS if new onset DAD } \\
\text { detected }>90 \text { days post-transplant }\end{array}$} \\
\hline & $\begin{array}{l}\text { - Can have outcome similar to primary } \\
\text { transplant following lung retransplantation }\end{array}$ & & \\
\hline
\end{tabular}

*Infection, other pathologies (e.g. acute cellular rejection, lymphocytic bronchiolitis, antibody-mediated rejection), and/or other causes of allograft dysfunction (e.g. significant gastroesophageal reflux, pleural disorders, anastomotic dysfunction, obesity, thromboembolic disease, recurrent primary lung disease, etc.), must be ruled out.

Abbreviations: $B A L=$ bronchoalveolar lavage; $B O S=$ bronchiolitis obliterans syndrome; $C L A D=$ chronic lung allograft dysfunction; $D A D=$ diffuse alveolar damage; NRAD = neutrophilic reversible allograft dysfunction; $O B=$ obliterative bronchiolitis; RAS = restrictive allograft syndrome

a hyperoncotic, acellular serum that dehydrates edematous lungs by drawing fluid from extravascular compartments such that gas exchange can be improved and lungs initially judged to be unsuitable for transplant can be rendered usable [30-32]. Additionally, anti-inflammatory cytokines can be infused into the lungs to promote injury repair, and vector-mediated transfer of interleukin (IL)-10 has been shown to decrease proinflammatory cytokine production, promote recovery of intercellular alveolar epithelial tight junctions, improve oxygenation, and decrease vascular resistance [33-35]. Antibiotics can also be infused to suppress/eliminate infection.

\section{Bridging to lung transplantation}

Transplantation of patients receiving life support in the intensive care unit and the use of extracorporeal membrane oxygenation (ECMO) to support patients with severe respiratory failure has gradually increased, but outcomes for patients on either mechanical ventilation or ECMO have been reported to be significantly lower than those who do not require such support [10,36-38]. Nonetheless, ECMO may provide the only means of keeping a patient alive for transplantation and can also be used to support recipients through the transplant procedure [39-44]. Newer approaches and devices for ECMO are being developed that can allow patients to be ambulatory while they await organ offers and transplantation [45-49]. Additionally, an external artificial lung (NovaLung system) has recently become available for patient use [50-53], and this paracorporeal system, which is typically not flow-assisted, can be connected to an external pump for circulatory assistance if needed.

\section{Infection prophylaxis}

Infections remain a constant threat to lung transplant recipients. However, prophylactic regimens can protect recipients from certain infections, and the advent of cytomegalovirus (CMV) prophylaxis has greatly reduced the impact of CMV disease on recipient survival $[54,55]$. A recent, well-conducted, randomized controlled trial of prophylaxis with valganciclovir for at-risk patients (donor or recipient CMV seropositive) showed a marked reduction in CMV disease incidence for a 12-month course of valganciclovir versus a 3-month course [56]. Additional investigations need to be undertaken to refine this and other approaches to infection prophylaxis.

\section{Detection and management of chronic lung allograft dysfunction}

The predominant cause of chronic lung allograft dysfunction (CLAD) is recognized to be BOS, which is perceived to be caused by obliterative bronchiolitis as a consequence of 
chronic rejection and has been linked to numerous risk factors (Table 2). The transplant community now recognizes that CLAD can be caused by a variety of allograft abnormalities [57-59], and the novel entities of restrictive allograft syndrome [60-62] and neutrophilic reversible allograft dysfunction (NRAD) [63] have been recently described and distinguished from classical BOS [64], which is recognized as an obstructive pattern on spirometry without parenchymal infiltrates in the allograft (Table 3). BOS is generally poorly responsive to augmented immunosuppression or other interventions, but recent randomized clinical trials have suggested that it can be prevented and/or attenuated by administering azithromycin $[65,66]$. Although preliminary work with inhaled cyclosporine A suggested benefit [67], a recent, multicenter Phase III clinical trial of inhaled aerosolized cyclosporine A given prophylactically for the primary outcome of BOSfree survival (294 subjects enrolled) was completed in 2011 and appears to have shown no benefit (see www. clinicaltrials.gov; NCT00755781).

Patients with advanced lung disease and lung transplant recipients frequently have a significantly increased degree of gastroesophageal reflux, and a number of investigations suggest that anti-reflux surgery may provide benefit for lung allograft recipients [68-74]. Other approaches such as photopheresis or the administration of intravenous immune globulin and/or anti-CD20 antibodies may benefit recipients with either refractory acute cellular rejection or BOS if evidence of a humoral response to donor antigen (donor-specific antibody) is detected [75-77]. Another recent advance is the recognition that autoimmunity (immune responses directed against selfantigens such as collagen $\mathrm{V}$ ) may play a significant role in both acute and chronic lung allograft rejection [78-82], and tolerization with oral administration of collagen $\mathrm{V}$ has been shown to blunt lung allograft rejection in a major histocompatibility (MHC)-mismatched animal model [83-86].

\section{Inducing tolerance}

IL-17-secreting lymphocytes (such as Th17 lymphocytes that have been associated with autoimmune disorders) have been identified as playing key roles in acute and chronic allograft rejection [78,87-96], and ongoing research has identified an expanded number of immune cell subsets that secrete IL-17 [96,97]. Regulatory lymphocyte subsets such as CD4+FoxP3+ T cells and B1 B cells can antagonize and suppress both allo- and autoimmune rejection responses [98-104]. A better understanding of regulatory cell mechanisms is evolving and may lead to novel approaches to prevent rejection by harnessing the ability of regulatory immune cells to suppress host rejection of implanted donor tissue and inflammation.

\section{Stem cells}

Donor-derived mesenchymal stem cells have been identified as potentially playing a significant role in bronchiolar fibrosis in BOS [105-107], possibly in part because they may be capable of inhibiting the function of various immune cells ( $\mathrm{T}$ cells, B cells, natural killer (NK) cells, dendritic cells) and cytokine secretion [108-110]. Stem cells have been shown to reduce injury and inflammation in a number of animal models [111-122], and stem cell therapies may blunt acute ischemia-reperfusion injury and fibrotic responses to lung injury.

\section{Tissue engineering}

Methods have been developed to decellularize whole lungs such that an intact extracellular matrix can be isolated, and these 3-dimensional scaffolds can be subsequently recellularized [123-126]. Such bioartificial lung grafts have been successfully placed orthotopically in animal models following successful recellularization with stem or progenitor cells and provide gas exchange, but delayed onset of inflammation and consolidation eventually led to loss of function $[127,128]$. Research is ongoing to determine whether a bioengineered lung can be adequately recellularized with appropriate stem cells that differentiate and replace/repopulate the more than 40 different cell types in their normal anatomic compartments such that sustained function can be attained, preferably with cells obtained from the prospective recipient so that the need for intense immunosuppression and risk of opportunistic infection can be avoided.

\section{Xenotransplantation}

Lung transplantation across species (e.g. pig lung to human recipient) may provide an alternative to allogeneic lung transplantation or could serve as a bridge to allotransplantation to allow time for a human donorrecipient match to be made and the xenograft replaced $[129,130]$. However, exuberant inflammatory, immune, and coagulation responses must be overcome [131-133]. Extensive genetic engineering of pigs is ongoing to prevent the acute thrombotic and severe inflammatory reactions that have occurred in various xenotransplant models, such as pig to primate xenotransplantation [129,134,135].

\section{Implications for clinical practice}

The implementation of the LAS system in the US has improved organ allocation and reduced the number of deaths on the waitlist; however, organs are being increasingly allocated to older candidates with pulmonary fibrosis. Refinement of the criteria used to select lung transplant candidates is needed and may lead to improved post-transplant outcomes if the ability to predict a greater likelihood of good versus poor post-transplant survival is 
improved. New HLA antibody detection techniques will allow better donor-recipient matching and prevent presensitized candidates from receiving mismatched donor lungs, and these techniques should be universally implemented by all transplant centers. The increased use of DCD donors and the use of marginal donor lungs that have been reconditioned via EVLP will likely significantly expand the number of transplants that can be performed, although supply is likely to remain inadequate to satisfy increasing demand. ECMO techniques have gradually improved such that patients with profound respiratory failure due to irreversible, end-stage lung disease can be supported until a match can be found, and the use of artificial lung devices and newer ECMO devices can allow patients to remain ambulatory prior to transplant and avoid invasive mechanical ventilation.

Advances in infection prophylaxis, especially prevention of CMV disease, have had an impact on post-transplant morbidity and mortality, and our understanding of CLAD has improved considerably over the past few years and has led to new approaches of the treatment of BOS, such as administration of azithromycin. An improved understanding of IL-17-mediated rejection responses and mechanisms of immune regulation that can prevent adverse allo- and autoimmune rejection responses may lead to novel strategies that can achieve immune tolerance and diminish the need for chronic, intense pharmacologic immunosuppression, which is associated with increased risk of adverse events (infection, renal insufficiency, systemic hypertension, hyperlipidemia, diabetes) over time. The utilization of stem cell therapies holds the promise of suppressing immune responses, but considerable research is needed to determine how stem cells can be used to prevent or ameliorate allograft rejection or injury. Tissue engineering with the restoration of cellular compartments of a lung scaffold using candidate progenitor cells and xenotransplantation (e.g. pig to human) are areas of intense research, but considerable hurdles must be overcome before these approaches can become realities in clinical lung transplantation.

\section{Abbreviations}

BOS, bronchiolitis obliterans syndrome; CLAD, chronic lung allograft dysfunction; CMV, cytomegalovirus; DCD, donation after cardiac death; ECMO, extra-corporeal membrane oxygenation; EVLP, ex-vivo lung perfusion; LAS, lung allocation score; MHC, major histocompatibility complex; MSC, mesenchymal stem cell; NK, natural killer; NRAD, neutrophilic reversible allograft dysfunction.

\section{Disclosures}

The author declares that he has no disclosures.

\section{Acknowledgments}

Supported in part by the George and Julie Mosher Pulmonary Research Fund.

The author thanks Meghan Holland for her assistance with the manuscript.

\section{References}

I. Kotloff RM, Thabut G: Lung transplantation. Am J Respir Crit Care Med 20II, I84:I59-7I.

2. Spahr J, Meyer K: Lung transplantation. In Primer on Transplantation. (3rd Edition). Edited by Hricik D, American Society of Transplantation. Oxford, UK: Wiley-Blackwell; 20 I I:205-37.

3. Eberlein M, Garrity ER, Orens JB: Lung allocation in the United States. Clin Chest Med 201 I, 32:213-22.

FlOOOPrime

4. Yusen RD, Shearon TH, Qian Y, Kotloff R, Barr ML, Sweet S, Dyke DB, Murray S: Lung transplantation in the United States, 1999-2008. Am J Transplant 2010, 10:1047-68.

5. Russo MJ, Iribarne A, Hong KN, Davies RR, Xydas S, Takayama H, Ibrahimiye A, Gelijns AC, Bacchetta MD, D'Ovidio F, Arcasoy S, Sonett JR: High lung allocation score is associated with increased morbidity and mortality following transplantation. Chest 2010, | 37:65 |-7.

6. Merlo CA, Weiss ES, Orens JB, Borja MC, Diener-West M, Conte JV, Shah AS: Impact of U.S. Lung Allocation Score on survival after lung transplantation. J Heart Lung Transplant 2009, 28:769-75.

7. Horai T, Shigemura N, Gries C, Pilewski J, Bhama JK, Bermudez CA, Zaldonis D, Toyoda Y: Lung transplantation for patients with high lung allocation score: single-center experience. Ann Thorac Surg 2012, 93: I592-7; discussion I597.

8. Russo MJ, Worku B, Iribarne A, Hong KN, Yang JA, Vigneswaran W, Sonett JR: Does lung allocation score maximize survival benefit from lung transplantation? I Thorac Cardiovasc Surg 201I, | 4 I: | 270-7.

9. Weiss ES, Allen JG, Merlo CA, Conte JV, Shah AS: Lung allocation score predicts survival in lung transplantation patients with pulmonary fibrosis. Ann Thorac Surg 2009, 88: I757-64.

10. George TJ, Beaty CA, Kilic A, Shah PD, Merlo CA, Shah AS: Outcomes and temporal trends among high-risk patients after lung transplantation in the United States. J Heart Lung Transplant 2012, 31:1 182-91.

\section{FlOOOPrime} RECOMMENDED

II. Kilic A, Merlo CA, Conte JV, Shah AS: Lung transplantation in patients $\mathbf{7 0}$ years old or older: have outcomes changed after implementation of the lung allocation score? J Thorac Cardiovasc Surg 2012, I44:1133-8.

\section{FlOOOPrime}

RECOMMENDED

12. Russo MJ, Davies RR, Hong KN, Iribarne A, Kawut S, Bacchetta M, D'Ovidio F, Arcasoy S, Sonett JR: Who is the high-risk recipient? Predicting mortality after lung transplantation using pretransplant risk factors. J Thorac Cardiovasc Surg 2009, I38: |234-|238.el.

13. Gries CJ, Rue TC, Heagerty PJ, Edelman JD, Mulligan MS, Goss CH: Development of a predictive model for long-term survival after lung transplantation and implications for the lung allocation score. J Heart Lung Transplant 2010, 29:731-8.

14. Hook JL, Lederer DJ: Selecting lung transplant candidates: where do current guidelines fall short? Expert Rev Respir Med 2012, 6:5 I-6I. 
15. Murphey CL, Forsthuber TG: Trends in HLA antibody screening and identification and their role in transplantation. Expert Rev Clin Immunol 2008, 4:391-9.

\section{FlOOOPrime}

\section{RECOMMENDED}

16. Tait BD, Hudson F, Cantwell L, Brewin G, Holdsworth R, Bennett G, Jose M: Review article: Luminex technology for HLA antibody detection in organ transplantation. Nephrology (Carlton) 2009, I 4:247-54.

17. Zangwill SD, Ellis TM, Zlotocha J, Jaquiss RD, Tweddell JS, Mussatto KA, Berger S: The virtual crossmatch-a screening tool for sensitized pediatric heart transplant recipients. Pediatr Transplant 2006, I0:38-4I.

18. Tambur AR, Ramon DS, Kaufman DB, Friedewald J, Luo X, Ho B, Skaro A, Caicedo J, Ladner D, Baker T, Fryer J, Gallon L, Miller J, Abecassis MM, Leventhal J: Perception versus reality?: Virtual crossmatch-how to overcome some of the technical and logistic limitations. Am J Transplant 2009, 9:1886-93.

19. Cecka JM, Kucheryavaya AY, Reinsmoen NL, Leffell MS: Calculated PRA: initial results show benefits for sensitized patients and a reduction in positive crossmatches. Am J Transplant 20 I I, I I:7 I9-24.

20. El-Awar N, Lee J, Terasaki PI: HLA antibody identification with single antigen beads compared to conventional methods. Hum Immunol 2005, 66:989-97.

21. Mason DP, Thuita L, Alster JM, Murthy SC, Budev MM, Mehta AC, Pettersson GB, Blackstone EH: Should lung transplantation be performed using donation after cardiac death? The United States experience. J Thorac Cardiovasc Surg 2008, 136:1061-6.

\section{FlOOOPrime}

22. de Oliveira NC, Osaki S, Maloney JD, Meyer KC, Kohmoto T, D'Alessandro AM, Love RB: Lung transplantation with donation after cardiac death donors: long-term follow-up in a single center. J Thorac Cardiovasc Surg 2010, 139:1306-15.

23. Wierup P, Haraldsson A, Nilsson F, Pierre L, Scherstén $H$, Silverborn M, Sjöberg T, Westfeldt U, Steen S: Ex vivo evaluation of nonacceptable donor lungs. Ann Thorac Surg 2006, 81:460-6.

\section{FlOOOPRime}

24. Cypel M, Yeung JC, Hirayama S, Rubacha M, Fischer S, Anraku M, Sato M, Harwood S, Pierre A, Waddell TK, de Perrot M, Liu M, Keshavjee $S$ : Technique for prolonged normothermic ex vivo lung perfusion. J Heart Lung Transplant 2008, 27:1319-25.

25. Cypel M, Rubacha M, Yeung J, Hirayama S, Torbicki K, Madonik M, Fischer S, Hwang D, Pierre A, Waddell TK, de Perrot M, Liu M, Keshavjee S: Normothermic ex vivo perfusion prevents lung injury compared to extended cold preservation for transplantation. Am J Transplant 2009, 9:2262-9.

26. Ingemansson R, Eyjolfsson A, Mared L, Pierre L, Algotsson L, Ekmehag B, Gustafsson R, Johnsson P, Koul B, Lindstedt S, Lührs C, Sjöberg T, Steen S: Clinical transplantation of initially rejected donor lungs after reconditioning ex vivo. Ann Thorac Surg 2009, 87:255-60.

27. Yeung JC, Cypel M, Waddell TK, van Raemdonck D, Keshavjee S: Update on donor assessment, resuscitation, and acceptance criteria, including novel techniques-non-heart-beating donor lung retrieval and ex vivo donor lung perfusion. Thorac Surg Clin 2009, 19:26I-74.

28. Cypel M, Yeung JC, Keshavjee S: Novel approaches to expanding the lung donor pool: donation after cardiac death and ex vivo conditioning. Clin Chest Med 20II, 32:233-44.

29. Cypel M, Keshavjee S: Extracorporeal lung perfusion. Curr Opin Organ Transplant 20II, 16:469-75.

30. Zych B, Popov AF, Stavri G, Bashford A, Bahrami T, Amrani M, de Robertis F, Carby M, Marczin N, Simon AR, Redmond KC: Early outcomes of bilateral sequential single lung transplantation after ex-vivo lung evaluation and reconditioning. J Heart Lung Transplant 2012, 3 I :274-8I.
3I. Sadaria MR, Smith PD, Fullerton DA, Justison GA, Lee JH, Puskas F, Grover FL, Cleveland JC, Reece TB, Weyant MJ: Cytokine expression profile in human lungs undergoing normothermic ex-vivo lung perfusion. Ann Thorac Surg 20II, 92:478-84.

\section{FlOOOPrime
RECOMMENDED}

32. Aigner C, Slama A, Hötzenecker K, Scheed A, Urbanek B, Schmid W, Nierscher FJ, Lang G, Klepetko W: Clinical ex vivo lung perfusion-pushing the limits. Am J Transplant 2012, 12:1839-47.

33. Cypel M, Liu M, Rubacha M, Yeung JC, Hirayama S, Anraku M, Sato M, Medin J, Davidson BL, de Perrot M, Waddell TK, Slutsky AS, Keshavjee S: Functional repair of human donor lungs by IL- 10 gene therapy. Sci Transl Med 2009, I:4ra9.

\section{FlOOOPrime
RECOMMENDED}

34. Yeung JC, Wagnetz D, Cypel M, Rubacha M, Koike T, Chun Y, Hu J, Waddell TK, Hwang DM, Liu M, Keshavjee S: Ex vivo adenoviral vector gene delivery results in decreased vector-associated inflammation pre- and post-lung transplantation in the pig. Mol Ther 2012, 20:1204-1I.

35. Cypel M, Keshavjee S: The clinical potential of ex vivo lung perfusion. Expert Rev Respir Med 2012, 6:27-35.

36. Mason DP, Thuita L, Nowicki ER, Murthy SC, Pettersson GB, Blackstone EH: Should lung transplantation be performed for patients on mechanical respiratory support? The US experience. J Thorac Cardiovasc Surg 2010, 139:765-773.el.

37. Gottlieb J, Warnecke G, Hadem J, Dierich M, Wiesner O, Fühner T, Strueber M, Haverich A, Welte T: Outcome of critically ill lung transplant candidates on invasive respiratory support. Intensive Care Med 2012, 38:968-75.

38. Bittner HB, Lehmann S, Rastan A, Garbade J, Binner C, Mohr FW, Barten MJ: Outcome of extracorporeal membrane oxygenation as a bridge to lung transplantation and graft recovery. Ann Thorac Surg 2012, 94:942-9; author reply 949-50.

39. Lang G, Taghavi S, Aigner C, Rényi-Vámos F, Jaksch P, Augustin V, Nagayama K, Ghanim B, Klepetko W: Primary lung transplantation after bridge with extracorporeal membrane oxygenation: a plea for a shift in our paradigms for indications. Transplantation 20I2, 93:729-36.

40. Javidfar J, Bacchetta M: Bridge to lung transplantation with extracorporeal membrane oxygenation support. Curr Opin Organ Transplant 2012, 17:496-502.

4I. Nosotti M, Rosso L, Tosi D, Palleschi A, Mendogni P, Nataloni IF, Crotti S, Tarsia P: Extracorporeal membrane oxygenation with spontaneous breathing as a bridge to lung transplantation. Interact Cardiovasc Thorac Surg 2013, 16:55-9.

42. lus F, Kuehn C, Tudorache I, Sommer W, Avsar M, Boethig D, Fuehner T, Gottlieb J, Hoeper M, Haverich A, Warnecke G: Lung transplantation on cardiopulmonary support: venoarterial extracorporeal membrane oxygenation outperformed cardiopulmonary bypass. J Thorac Cardiovasc Surg 2012, I44:1510-6.

43. Shafii AE, Mason DP, Brown CR, Vakil N, Johnston DR, McCurry KR, Pettersson GB, Murthy SC: Growing experience with extracorporeal membrane oxygenation as a bridge to lung transplantation. ASAIO J 2012, 58:526-9.

44. Javidfar J, Brodie D, Iribarne A, Jurado J, Lavelle M, Brenner K, Arcasoy S, Sonett J, Bacchetta M: Extracorporeal membrane oxygenation as a bridge to lung transplantation and recovery. J Thorac Cardiovasc Surg 2012, 144:7|6-2I.

45. Garcia JP, lacono A, Kon ZN, Griffith BP: Ambulatory extracorporeal membrane oxygenation: a new approach for bridge-to-lung transplantation. J Thorac Cardiovasc Surg 2010, 139:el37-9.

\section{FlO0OPrime \\ RECOMMENDED}

46. Shafii AE, McCurry KR: Subclavian insertion of the bicaval dual lumen cannula for venovenous extracorporeal membrane oxygenation. Ann Thorac Surg 2012, 94:663-5. 
47. Mangi AA, Mason DP, Yun J], Murthy SC, Pettersson GB: Bridge to lung transplantation using short-term ambulatory extracorporeal membrane oxygenation. J Thorac Cardiovasc Surg 2010, 140:713-5.

48. Lowman JD, Kirk TK, Clark DE: Physical therapy management of a patient on portable extracorporeal membrane oxygenation as a bridge to lung transplantation: a case report. Cardiopulm Phys Ther $J$ 2012, 23:30-5.

49. Garcia JP, Kon ZN, Evans C, Wu Z, lacono AT, McCormick B, Griffith BP: Ambulatory veno-venous extracorporeal membrane oxygenation: innovation and pitfalls. J Thorac Cardiovasc Surg 20II, I42:755-6I.

50. Ricci D, Boffini M, Del Sorbo L, El Qarra S, Comoglio C, Ribezzo M, Bonato R, Ranieri VM, Rinaldi M: The use of $\mathrm{CO} 2$ removal devices in patients awaiting lung transplantation: an initial experience. Transplant Proc 2010, 42:1255-8.

51. Camboni D, Philipp A, Hirt S, Schmid C: Possibilities and limitations of a miniaturized long-term extracorporeal life support system as bridge to transplantation in a case with biventricular heart failure. Interact Cardiovasc Thorac Surg 2009, 8:168-70.

52. Taylor $\mathrm{K}$, Holtby $\mathrm{H}$ : Emergency interventional lung assist for pulmonary hypertension. Anesth Analg 2009, 109:382-5.

\section{FlOOOPrime}

\section{RECOMMENDED}

53. Camboni D, Philipp A, Haneya A, Puehler T, Arlt M, Hilker M, Schmid FX, Schmid C: Serial use of an interventional lung assist device and a ventricular assist device. ASAIO J 2010, 56:270-2.

\section{FlOOOPrime}

\section{RECOMMENDED}

54. Kotton CN, Kumar D, Caliendo AM, Asberg A, Chou S, Snydman DR, Allen U, Humar A: International consensus guidelines on the management of cytomegalovirus in solid organ transplantation. Transplantation 2010, 89:779-95.

55. Hodson EM, Craig JC, Strippoli GFM, Webster AC: Antiviral medications for preventing cytomegalovirus disease in solid organ transplant recipients. Cochrane Database Syst Rev 2008: CD003774.

56. Palmer SM, Limaye AP, Banks M, Gallup D, Chapman J, Lawrence EC, Dunitz J, Milstone A, Reynolds J, Yung GL, Chan KM, Aris R, Garrity E, Valentine V, McCall J, Chow S, Davis RD, Avery R: Extended valganciclovir prophylaxis to prevent cytomegalovirus after lung transplantation: a randomized, controlled trial. Ann Intern Med 2010, 152:761-9.

\section{FlOOOPrime}

\section{RECOMMENDED}

57. Verleden GM, Vos R, de Vleeschauwer SI, Willems-Widyastuti A, Verleden SE, Dupont LJ, van Raemdonck DEM, Vanaudenaerde BM: Obliterative bronchiolitis following lung transplantation: from old to new concepts? Transpl Int 2009, 22:77I-9.

\section{FlOOOPRime
RECOMMENDED}

58. Todd JL, Palmer SM: Bronchiolitis obliterans syndrome: the final frontier for lung transplantation. Chest 20II, 140:502-8.

59. Meyer KC: Bronchiolitis obliterans syndrome. Curr Respir Care Rep 2012, I:147-56.

60. Sato M, Waddell TK, Wagnetz U, Roberts HC, Hwang DM, Haroon A, Wagnetz D, Chaparro C, Singer LG, Hutcheon MA, Keshavjee S: Restrictive allograft syndrome (RAS): a novel form of chronic lung allograft dysfunction. J Heart Lung Transplant 20II, 30:735-42.

6I. Verleden GM, Vos R, Verleden SE, de Wever W, de Vleeschauwer SI, Willems-Widyastuti A, Scheers H, Dupont LJ, van Raemdonck DE, Vanaudenaerde BM: Survival determinants in lung transplant patients with chronic allograft dysfunction. Transplantation 201 I, 92:703-8.

62. Woodrow JP, Shlobin OA, Barnett SD, Burton N, Nathan SD: Comparison of bronchiolitis obliterans syndrome to other forms of chronic lung allograft dysfunction after lung transplantation. J Heart Lung Transplant 2010, 29:1 159-64.

\section{FlOOOPrime}

63. Vos R, Vanaudenaerde BM, Ottevaere A, Verleden SE, de Vleeschauwer SI, Willems-Widyastuti A, Wauters S, van Raemdonck DE, Nawrot TS, Dupont LJ, Verleden GM: Long-term azithromycin therapy for bronchiolitis obliterans syndrome: divide and conquer? J Heart Lung Transplant 2010, 29:1358-68.

\section{FIOOOPrime
RECOMMENDED}

64. Estenne M, Maurer JR, Boehler A, Egan JJ, Frost A, Hertz M, Mallory GB, Snell GI, Yousem S: Bronchiolitis obliterans syndrome 200I: an update of the diagnostic criteria. J Heart Lung Transplant 2002, 21:297-310.

65. Vos R, Vanaudenaerde BM, Verleden SE, de Vleeschauwer SI, WillemsWidyastuti A, van Raemdonck DE, Schoonis A, Nawrot TS, Dupont LJ, Verleden GM: A randomised controlled trial of azithromycin to prevent chronic rejection after lung transplantation. Eur Respir J 20II, 37:164-72.

FlOOOPrime RECOMMENDED

66. Yates B, Murphy DM, Forrest IA, Ward C, Rutherford RM, Fisher AJ, Lordan JL, Dark JH, Corris PA: Azithromycin reverses airflow obstruction in established bronchiolitis obliterans syndrome. Am J Respir Crit Care Med 2005, 172:772-5.

67. lacono AT, Johnson BA, Grgurich WF, Youssef JG, Corcoran TE, Seiler DA, Dauber JH, Smaldone GC, Zeevi A, Yousem SA, Fung J], Burckart G], McCurry KR, Griffith BP: A randomized trial of inhaled cyclosporine in lung-transplant recipients. $N$ Engl $J$ Med 2006, 354:14I-50.

68. Gasper WJ, Sweet MP, Hoopes C, Leard LE, Kleinhenz ME, Hays SR, Golden JA, Patti MG: Antireflux surgery for patients with endstage lung disease before and after lung transplantation. Surg Endosc 2008, 22:495-500.

69. Hoppo T, Jarido V, Pennathur A, Morrell M, Crespo M, Shigemura N, Bermudez C, Hunter JG, Toyoda Y, Pilewski J, Luketich JD, Jobe BA: Antireflux surgery preserves lung function in patients with gastroesophageal reflux disease and end-stage lung disease before and after lung transplantation. Arch Surg 20I I, I 46: I 04 I-7. FIOOOPrime

70. Cantu E, Appel JZ, Hartwig MG, Woreta H, Green C, Messier R, Palmer SM, Davis RD: J. Maxwell Chamberlain Memorial Paper. Early fundoplication prevents chronic allograft dysfunction in patients with gastroesophageal reflux disease. Ann Thorac Surg 2004, 78: ||42-5|; discussion ||42-5|.

7I. Davis RD, Lau CL, Eubanks S, Messier RH, Hadjiliadis D, Steele MP, Palmer SM: Improved lung allograft function after fundoplication in patients with gastroesophageal reflux disease undergoing lung transplantation. J Thorac Cardiovasc Surg 2003, 125:533-42.

72. Mertens V, Blondeau K, Pauwels A, Farre R, Vanaudenaerde B, Vos R, Verleden G, van Raemdonck DE, Dupont LJ, Sifrim D: Azithromycin reduces gastroesophageal reflux and aspiration in lung transplant recipients. Dig Dis Sci 2009, 54:972-9.

73. Mertens V, Blondeau K, van Oudenhove L, Vanaudenaerde B, Vos R, Farre R, Pauwels A, Verleden G, van Raemdonck D, Sifrim D, Dupont LJ: Bile acids aspiration reduces survival in lung transplant recipients with BOS despite azithromycin. Am J Transplant 201 I, I I:329-35.

74. Bobadilla JL, Jankowska-Gan E, Xu Q, Haynes LD, Munoz del Rio A, Meyer K, Greenspan DS, de Oliveira N, Burlingham WJ, Maloney JD: Reflux-induced collagen type $v$ sensitization: potential mediator of bronchiolitis obliterans syndrome. Chest 2010, 138:363-70.

75. Jaksch P, Scheed A, Keplinger M, Ernst M, Dani T, Just U, Nahavandi $H$, Klepetko W, Knobler R: A prospective interventional study on the use of extracorporeal photopheresis in 
patients with bronchiolitis obliterans syndrome after lung transplantation. J Heart Lung Transplant 2012, 31:950-7.

\section{FIOOOPrime}

76. Marques MB, Schwartz J: Update on extracorporeal photopheresis in heart and lung transplantation. J Clin Apher 20I I, 26: I46-5 I.

\section{FlOOOPrime \\ RECOMMENDED}

77. Hachem RR, Yusen RD, Meyers BF, Aloush AA, Mohanakumar T, Patterson GA, Trulock EP: Anti-human leukocyte antigen antibodies and preemptive antibody-directed therapy after lung transplantation. J Heart Lung Transplant 2010, 29:973-80.

78. Burlingham WJ, Love RB, Jankowska-Gan E, Haynes LD, Xu Q, Bobadilla JL, Meyer KC, Hayney MS, Braun RK, Greenspan DS, Gopalakrishnan B, Cai J, Brand DD, Yoshida S, Cummings OW, Wilkes DS: IL-I 7-dependent cellular immunity to collagen type V predisposes to obliterative bronchiolitis in human lung transplants. J Clin Invest 2007, I I 7:3498-506.

79. Bobadilla JL, Love RB, Jankowska-Gan E, Xu Q, Haynes LD, Braun RK, Hayney MS, Munoz del Rio A, Meyer K, Greenspan DS, Torrealba J, Heidler KM, Cummings OW, Iwata $T$, Brand $D$, Presson $R$, Burlingham WJ, Wilkes DS: Th-I 7, monokines, collagen type V, and primary graft dysfunction in lung transplantation. Am J Respir Crit Care Med 2008, 177:660-8.

80. Saini D, Weber J, Ramachandran S, Phelan D, Tiriveedhi V, Liu M, Steward N, Aloush A, Hachem R, Trulock E, Meyers B, Patterson GA, Mohanakumar T: Alloimmunity-induced autoimmunity as a potential mechanism in the pathogenesis of chronic rejection of human lung allografts. J Heart Lung Transplant 20I I, 30:624-3I.

8I. Hachem RR, Tiriveedhi V, Patterson GA, Aloush A, Trulock EP, Mohanakumar T: Antibodies to K- $\alpha$ I tubulin and collagen $V$ are associated with chronic rejection after lung transplantation. Am J Transplant 2012, 12:2164-71.

82. Takenaka $M$, Subramanian V, Tiriveedhi V, Phelan D, Hachem $R$, Trulock E, Gelman AE, Patterson GA, Hoshinaga K, Mohanakumar T: Complement activation is not required for obliterative airway disease induced by antibodies to major histocompatibility complex class I: Implications for chronic lung rejection. J Heart Lung Transplant 2012, 31:1214-22.

83. Yasufuku K, Heidler KM, O'Donnell PW, Smith GN, Cummings OW, Foresman $\mathrm{BH}$, Fujisawa T, Wilkes DS: Oral tolerance induction by type $\mathbf{V}$ collagen downregulates lung allograft rejection. $\mathrm{Am} J$ Respir Cell Mol Biol 200I, 25:26-34.

\section{FlOOOPrime
RECOMMENDED}

84. Yasufuku K, Heidler KM, Woods KA, Smith GN, Cummings OW, Fujisawa T, Wilkes DS: Prevention of bronchiolitis obliterans in rat lung allografts by type $\mathbf{V}$ collagen-induced oral tolerance. Transplantation 2002, 73:500-5.

85. Mizobuchi T, Yasufuku K, Zheng Y, Haque MA, Heidler KM, Woods K, Smith GN, Cummings OW, Fujisawa T, Blum JS, Wilkes DS: Differential expression of Smad7 transcripts identifies the CD4+CD45RChigh regulatory $T$ cells that mediate type $V$ collagen-induced tolerance to lung allografts. J Immunol 2003, I7I: | |40-7.

86. Yamada Y, Sekine Y, Yoshida S, Yasufuku K, Petrache I, Benson HL, Brand DD, Yoshino I, Wilkes DS: Type V collagen-induced oral tolerance plus low-dose cyclosporine prevents rejection of MHC class I and II incompatible lung allografts. J Immunol 2009, I 83:237-45

87. Vanaudenaerde BM, de Vleeschauwer SI, Vos R, Meyts I, Bullens DM, Reynders V, Wuyts WA, van Raemdonck DE, Dupont LJ, Verleden GM: The role of the IL23/ILI7 axis in bronchiolitis obliterans syndrome after lung transplantation. Am J Transplant 2008, 8: |9||-20.

88. Afzali B, Lombardi G, Lechler RI, Lord GM: The role of T helper 17 (ThI7) and regulatory $T$ cells (Treg) in human organ transplantation and autoimmune disease. Clin Exp Immunol 2007, | 148:32-46.

89. Tiriveedhi V, Takenaka M, Ramachandran S, Gelman AE, Subramanian V, Patterson GA, Mohanakumar T: T regulatory cells play a significant role in modulating MHC class I antibody-induced obliterative airway disease. Am J Transplant 2012, I 2:2663-74.

90. Fukami N, Ramachandran S, Takenaka M, Weber J, Subramanian V, Mohanakumar T: An obligatory role for lung infiltrating B cells in the immunopathogenesis of obliterative airway disease induced by antibodies to MHC class I molecules. Am J Transplant 2012, I 2:867-76.

91. Serody JS, Hill GR: The IL-I7 differentiation pathway and its role in transplant outcome. Biol Blood Marrow Transplant 2012, I 8: S56-6I.

92. Shilling RA, Wilkes DS: Role of ThI7 cells and IL-I7 in lung transplant rejection. Semin Immunopathol 20I I, 33:I29-34

93. Krebs R, Tikkanen JM, Ropponen JO, Jeltsch M, Jokinen JJ, Ylä-Herttuala S, Nykänen $\mathrm{Al}$, Lemström KB: Critical role of VEGF-C/VEGFR-3 signaling in innate and adaptive immune responses in experimental obliterative bronchiolitis. Am J Pathol 20I2, I8I:1607-20.

94. Tesar BM, Du W, Shirali AC, Walker WE, Shen H, Goldstein DR: Aging augments IL-I7 T-cell alloimmune responses. Am J Transplant 2009, 9:54-63.

\section{FIOOOPrime
RECOMMENDED}

95. Vanaudenaerde BM, Dupont LJ, Wuyts WA, Verbeken EK, Meyts I, Bullens DM, Dilissen E, Luyts L, van Raemdonck DE, Verleden GM: The role of interleukin-I 7 during acute rejection after lung transplantation. Eur Respir J 2006, 27:779-87.

96. Vanaudenaerde BM, Wuyts WA, Dupont LJ, van Raemdonck DE, Demedts MM, Verleden GM: Interleukin- 7 stimulates release of interleukin- 8 by human airway smooth muscle cells in vitro: a potential role for interleukin-I7 and airway smooth muscle cells in bronchiolitis obliterans syndrome. J Heart Lung Transplant 2003, 22:1280-3.

97. Vanaudenaerde BM, Verleden SE, Vos R, de Vleeschauwer SI, WillemsWidyastuti A, Geenens R, van Raemdonck DE, Dupont LJ, Verbeken EK, Meyts I: Innate and adaptive interleukin- I7-producing lymphocytes in chronic inflammatory lung disorders. Am J Respir Crit Care Med 20I I, I 83:977-86

98. Shi Q, Cao H, Liu J, Zhou X, Lan Q, Zheng S, Liu Z, Li Q, Fan H: CD4+ Foxp3+ regulatory $T$ cells induced by TGF- $\beta$, IL-2 and all-trans retinoic acid attenuate obliterative bronchiolitis in rat trachea transplantation. Int Immunopharmacol 201 I, I I: I 887-94.

\section{FlOOOPrime}

\section{RECOMMENDED}

99. Neujahr DC, Larsen CP: Regulatory T cells in lung transplantationan emerging concept. Semin Immunopathol 201 I, 33: I I 7-27.

100. Braun RK, Molitor-Dart M, Wigfield C, Xiang Z, Fain SB, JankowskaGan E, Seroogy CM, Burlingham WJ, Wilkes DS, Brand DD, Torrealba J, Love RB: Transfer of tolerance to collagen type V suppresses T-helper-cell-I 7 lymphocyte-mediated acute lung transplant rejection. Transplantation 2009, 88: | 34|-8.

10I. Jaffar Z, Ferrini ME, Girtsman TA, Roberts K: Antigen-specific Treg regulate ThI7-mediated lung neutrophilic inflammation, B-cell recruitment and polymeric IgA and IgM levels in the airways. Eur J Immunol 2009, 39:3307-I4.

\section{FlOOOPrime \\ RECOMMENDED}

102. Griffin DO, Rothstein TL: Human “orchestrator" CDI Ib(+) B I cells spontaneously secrete interleukin- $I 0$ and regulate $T$-cell activity. Mol Med 2012, 18:1003-8.

103. Mauri C, Bosma A: Immune regulatory function of B cells. Annu Rev Immunol 2012, 30:221-4I.

104. Li W, Bribriesco AC, Nava RG, Brescia AA, Ibricevic A, Spahn JH, Brody SL, Ritter JH, Gelman AE, Krupnick AS, Miller MJ, Kreisel D: Lung transplant acceptance is facilitated by early events in 
the graft and is associated with lymphoid neogenesis. Mucosal Immunol 2012, 5:544-54.

105. Lama VN, Smith L, Badri L, Flint A, Andrei A, Murray S, Wang Z, Liao H, Toews GB, Krebsbach PH, Peters-Golden M, Pinsky DJ, Martinez FJ, Thannickal VJ: Evidence for tissue-resident mesenchymal stem cells in human adult lung from studies of transplanted allografts. J Clin Invest 2007, I I 7:989-96.

\section{FIOOOPrime \\ RECOMMENDED}

106. Walker N, Badri L, Wettlaufer S, Flint A, Sajjan U, Krebsbach PH, Keshamouni VG, Peters-Golden M, Lama VN: Resident tissue-specific mesenchymal progenitor cells contribute to fibrogenesis in human lung allografts. Am J Pathol 20I I, I 78:246I-9.

107. Badri L, Murray S, Liu LX, Walker NM, Flint A, Wadhwa A, Chan KM, Toews GB, Pinsky DJ, Martinez FJ, Lama VN: Mesenchymal stromal cells in bronchoalveolar lavage as predictors of bronchiolitis obliterans syndrome. Am J Respir Crit Care Med 201 I, I 83: 1062-70.

108. de Miguel MP, Fuentes-Julián S, Blázquez-Martínez A, Pascual CY, Aller MA, Arias J, Arnalich-Montiel F: Immunosuppressive properties of mesenchymal stem cells: advances and applications. Curr Mol Med 2012, I 2:574-91.

109. Yi T, Song SU: Immunomodulatory properties of mesenchymal stem cells and their therapeutic applications. Arch Pharm Res 2012, 35:2|3-2|.

I I0. Jarvinen L, Badri L, Wettlaufer S, Ohtsuka T, Standiford TJ, Toews GB, Pinsky DJ, Peters-Golden M, Lama VN: Lung resident mesenchymal stem cells isolated from human lung allografts inhibit $T$ cell proliferation via a soluble mediator. J Immunol 2008, I 8 I:4389-96.

\section{FlOOOPrime}

RECOMMENDED

III. Banerjee ER, Laflamme MA, Papayannopoulou T, Kahn M, Murry CE, Henderson WR: Human embryonic stem cells differentiated to lung lineage-specific cells ameliorate pulmonary fibrosis in a xenograft transplant mouse model. PLOS ONE 2012, 7:e33165.

\section{FlOOOPrime \\ RECOMMENDED}

1 12. Sun C, Yen C, Lin Y, Tsai T, Chang L, Kao Y, Chua S, Fu M, Ko S, Leu S, Yip $\mathrm{H}$ : Autologous transplantation of adipose-derived mesenchymal stem cells markedly reduced acute ischemia-reperfusion lung injury in a rodent model. J Transl Med 201 I, 9:1 18.

\section{FlOOOPrime}

RECOMMENDED

I I 3. Chien M, Bien M, Ku C, Chang Y, Pao H, Yang Y, Hsiao M, Chen C, HoJH: Systemic human orbital fat-derived stem/stromal cell transplantation ameliorates acute inflammation in lipopolysaccharide-induced acute lung injury. Crit Care Med 2012, 40:1245-53.

I 14. Danchuk S, Ylostalo JH, Hossain F, Sorge R, Ramsey A, Bonvillain RW, Lasky JA, Bunnell BA, Welsh DA, Prockop DJ, Sullivan DE: Human multipotent stromal cells attenuate lipopolysaccharideinduced acute lung injury in mice via secretion of tumor necrosis factor- $\alpha$-induced protein 6. Stem Cell Res Ther 201 I, 2:27.

\section{FlOOOPrime}

I I5. Saito S, Nakayama T, Hashimoto N, Miyata Y, Egashira K, Nakao N, Nishiwaki S, Hasegawa M, Hasegawa Y, Naoe T: Mesenchymal stem cells stably transduced with a dominant-negative inhibitor of CCL2 greatly attenuate bleomycin-induced lung damage. $\mathrm{Am} J$ Pathol 2011, I79:1088-94.

I 16. Hegab AE, Ha VL, Gilbert JL, Zhang KX, Malkoski SP, Chon AT, Darmawan DO, Bisht B, Ooi AT, Pellegrini M, Nickerson DW, Gomperts BN: Novel stem/progenitor cell population from murine tracheal submucosal gland ducts with multipotent regenerative potential. Stem Cells 201 I, 29:1283-93.

I 17. Huh JW, Kim S, Lee JH, Lee J, van Ta Q, Kim M, Oh Y, Lee Y, Lee S: Bone marrow cells repair cigarette smoke-induced emphysema in rats. Am J Physiol Lung Cell Mol Physiol 20I I, 30 I:L255-66.
I 18. Firinci F, Karaman M, Baran Y, Bagriyanik A, Ayyildiz ZA, Kiray M, Kozanoglu I, Yilmaz O, Uzuner N, Karaman O: Mesenchymal stem cells ameliorate the histopathological changes in a murine model of chronic asthma. Int Immunopharmacol 20 I I, I I: I I 20-6.

I19. Chang YS, Choi SJ, Sung DK, Kim SY, Oh W, Yang YS, Park WS: Intratracheal transplantation of human umbilical cord blood derived mesenchymal stem cells dose-dependently attenuates hyperoxia-induced lung injury in neonatal rats. Cell Transplant 2011.

120. Toya SP, Li F, Bonini MG, Gomez I, Mao M, Bachmaier KW, Malik AB: Interaction of a specific population of human embryonic stem cell-derived progenitor cells with CDIIb+ cells ameliorates sepsis-induced lung inflammatory injury. Am J Pathol $2011,178: 313-24$.

121. Liang OD, Mitsialis SA, Chang MS, Vergadi E, Lee C, Aslam M, Fernandez-Gonzalez A, Liu X, Baveja R, Kourembanas S: Mesenchymal stromal cells expressing heme oxygenase-I reverse pulmonary hypertension. Stem Cells 201 I, 29:99-107.

122. Moodley Y, Atienza D, Manuelpillai U, Samuel CS, Tchongue J, llancheran S, Boyd R, Trounson A: Human umbilical cord mesenchymal stem cells reduce fibrosis of bleomycin-induced lung injury. Am J Pathol 2009, I 75:303-13.

123. Song JJ, Ott HC: Bioartificial lung engineering. Am J Transplant 2012, 12:283-8.

124. Bonvillain RW, Danchuk S, Sullivan DE, Betancourt AM, Semon JA Eagle ME, Mayeux JP, Gregory AN, Wang G, Townley IK, Borg ZD, Weiss DJ, Bunnell BA: A nonhuman primate model of lung regeneration: detergent-mediated decellularization and initial in vitro recellularization with mesenchymal stem cells. Tissue Eng Part A 2012, 18:2437-52.

125. Price AP, England KA, Matson AM, Blazar BR, Panoskaltsis-Mortari A Development of a decellularized lung bioreactor system for bioengineering the lung: the matrix reloaded. Tissue Eng Part $A$ 2010, 16:2581-9|

\section{FlOOPPine}

\section{RECOMMENDED}

126. Fritsche CS, Simsch O, Weinberg EJ, Orrick B, Stamm C, KaazempurMofrad MR, Borenstein JT, Hetzer R, Vacanti JP: Pulmonary tissue engineering using dual-compartment polymer scaffolds with integrated vascular tree. Int J Artif Organs 2009, 32:70 I-I0.

\section{FlOOOPrime
RECOMMENDED}

127. Ott HC, Clippinger B, Conrad C, Schuetz C, Pomerantseva I, Ikonomou L, Kotton D, Vacanti JP: Regeneration and orthotopic transplantation of a bioartificial lung. Nat Med 2010, 16:927-33.

\section{FIOOOPrime
RECOMMENDED}

128. Song JJ, Kim SS, Liu Z, Madsen JC, Mathisen DJ, Vacanti JP, Ott HC: Enhanced in vivo function of bioartificial lungs in rats. Ann Thorac Surg 201 I, 92:998-1005; discussion 1005-6.

\section{FlOOOPrime}

129. Cooper DKC, Ekser B, Burlak C, Ezzelarab M, Hara H, Paris L, Tector AJ, Phelps C, Azimzadeh AM, Ayares D, Robson SC, Pierson RN: Clinical lung xenotransplantation-what donor genetic modifications may be necessary? Xenotransplantation 2012, I 9: |44-58.

130. Burdorf L, Azimzadeh AM, Pierson RN: Xenogeneic lung transplantation models. Methods $\mathrm{Mol}$ Biol 2012, 885:169-89.

131. Gaca JG, Lesher A, Aksoy O, Gonzalez-Stawinski GV, Platt JL, Lawson JH, Parker W, Davis RD: Disseminated intravascular coagulation in association with pig-to-primate pulmonary xenotransplantation. Transplantation 2002, 73:1717-23.

132. Cantu E, Gaca JG, Palestrant D, Baig K, Lukes DJ, Gibson SE, GonzalezStawinski GV, Olausson M, Parker W, Davis RD: Depletion of pulmonary intravascular macrophages prevents hyperacute pulmonary xenograft dysfunction. Transplantation 2006, 81: I I 57-64. 
133. Li S, Waer M, Billiau AD: Xenotransplantation: role of natural immunity. Transpl Immunol 2009, 21:70-4.

134. Puga Yung GL, Li Y, Borsig L, Millard A, Karpova MB, Zhou D, Seebach JD: Complete absence of the $\alpha \mathrm{Gal}$ xenoantigen and isoglobotrihexosylceramide in $\alpha \mathrm{I}, 3$ galactosyltransferase knock-out pigs. Xenotransplantation 2012, 19:196-206.
135. Ekser B, Bianchi J, Ball S, Iwase H, Walters A, Ezzelarab M, Veroux M, Gridelli B, Wagner R, Ayares D, Cooper DKC: Comparison of hematologic, biochemical, and coagulation parameters in $\alpha \mathrm{l}, 3$-galactosyltransferase gene-knockout pigs, wild-type pigs, and four primate species. Xenotransplantation 2012, 19: 342-54.

FlOOOPrime

RECOMMENDED 